\section{Leadership styles and employees' work outcomes in nonprofit organizations: the role of work engagement}

\author{
Mohammed Aboramadan \\ Department of Economics, Management and Statistics, University of Milano-Bicocca, \\ Milano, Italy, and \\ Khalid Abed Dahleez \\ Department of Management, A'Sharqiyah University, Ibra, Oman and \\ Department of Management, Islamic University of Gaza, Gaza, Palestinian Authority
}

Leadership styles in nonprofit organizations \\ 869}

Received 18 December 2019

Revised 16 March 2020 24 April 2020

Accepted 11 May 2020

\begin{abstract}
Purpose - This study aims to investigate the effects of transformational and transactional leaders' behaviors on employees' affective commitment and organizational citizenship behavior in the context of nonprofit organizations (NPOs). Additionally, this study attempts to examine the role of work engagement, as an intervening mechanism as work engagement in NPOs has been empirically neglected (Park et al., 2018).

Design/methodology/approach - Data were conducted from 400 employees working in Italian NPOs in the North of Italy. For verifying the hypotheses of this study, structural equation modeling techniques were implemented.

Findings - It was found that both transformational and transactional leaderships influenced positively affective commitment and organizational citizenship behavior, and work engagement was revealed to have significant positive mediating effects on the relationship between the variables examined in this study.

Practical implications - The results of this study may be beneficial to leaders and supervisors of NPOs, specifically regarding the influence of the leaders' behaviors on the employees' outcomes.

Originality/value - Due to the limited number of studies conducted on leadership in nonprofit organizations, this study theoretically and empirically contributes to the leadership literature as it is the first study to investigate the two styles of leadership on work-related outcomes via work engagement in the nonprofit sector.
\end{abstract}

Keywords Affective commitment, Leadership, Italy, OCB, Nonprofit organization, Work engagement

Paper type Research paper

\section{Introduction}

Currently, organizations, including NPOs, have been faced with fast-changing environment, complexities and globalization, which gained the attention of HR professionals regarding the importance of leadership in organizations due to its influence on service quality, employees' retention and their overall business performance (Barling et al., 1996; Parry and Sinha, 2005; Sirianni and Frey, 2001).

In NPOs, it can be seen from the increasing importance of these organizations that the leaders of these organizations are faced with significantly complicated managerial tasks and duties (Fowler, 2013b; Lewis, 2001), including scarce resources and ambiguous work environments, suggesting that leaders in NPOs need to possess the competencies and attributes found in managers. Specifically, leaders in these organizations require effective

(C) Mohammed Aboramadan and Khalid Abed Dahleez. Published by Emerald Publishing Limited. This article is published under the Creative Commons Attribution (CC BY 4.0) licence. Anyone may reproduce, distribute, translate and create derivative works of this article (for both commercial and non-commercial purposes), subject to full attribution to the original publication and authors. The full terms of this licence may be seen at http://creativecommons.org/licences/by/4.0/legalcode

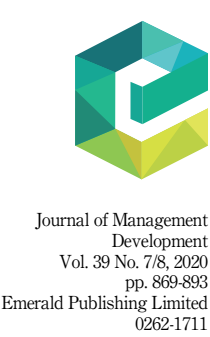

DOI 10.1108/JMD-12-2019-0499 
$\mathrm{JMD}$ $39,7 / 8$

managerial ability, personal integrity, vision and aspiration to successfully work with volunteers and employees of their organizations.

Leadership is seen as an interpersonal influence occurring through a communication system with the objective of achieving the organization's goals (Birasnav, 2014). It has also been documented in previous studies that leadership could influence organizations and individuals (Hentrich et al., 2017; Humphrey, 2012), which could be seen from an effective leader who is capable of influencing the followers to behave in a manner, which promotes positive outcomes for the organization. Furthermore, these leaders contribute to more benefits to the workplace compared to any other human resource in the organization (Gibson et al., 1991). Therefore, leadership that is capable of influencing employees' performance, satisfaction, and effectiveness (Turner and Muller, 2005) and promoting positive employee's attitudes (Bhal and Ansari, 2007) is crucial in the organization.

In general, leadership as a topic of research has been a significant field of study since the past decade.

Works of research primarily focused on transformational and transactional leadership styles (Bass and Avolio, 1993; Hassi, 2018; Rowold and Rohmann, 2009; Tims et al., 2011; Vecchio et al., 2008), which have been proven as highly useful approaches of increasing the effectiveness of leaders (Boehm et al., 2015). In this case, leaders are capable of stimulating, mobilizing and inspiring their employees to achieve the desired objectives (Andersen, 2016). Several scholars have approached the subject of leadership in terms of the influence of the leaders' behaviors on their followers (Clawson, 2008). It is documented in previous literature that leadership influences the work outcomes of the employees, including satisfaction, commitment, citizenship behaviors and innovation (Alkahtani, 2015; Chandra and Priyono, 2016; Haghighi and Maleki, 2016; Hassi, 2018; Le and Lei, 2017; Walumbwa et al., 2005; Yao et al., 2014; Yildız et al., 2014). More specifically, transformational and transactional leadership were found to affect employees' attitudes and behaviors (Bono and Judge, 2003; Judge and Piccolo, 2004).

Despite the increasing awareness of the significance of leadership in NPOs, the roles of the leaders were discussed in a few works of literature (Cornforth, 2014; Parsehyan, 2017). To illustrate, although the transformational-transactional leadership stream had been widely discussed in the business sector, this subject was overlooked in NPOs (Rowold and Rohman, 2009). Furthermore, most of the works of leadership research in NPOs were mainly based on the analysis of boards rather than the individual styles of leadership (Hailey, 2006). Recently, several endeavors have been carried out to add more insights into the leadership literature in NPOs. To illustrate, some researchers examined the participative and instrumental types of leadership and their impact on work engagement in the social cooperatives in Italy (Sarti, 2014), the impact of transformational leaders on organizational culture and NGOs effectiveness in Indian NGOs (Shiva and Suar, 2012), the impact of transformational leadership on culture and innovation in the nonprofit organizations in the USA (Jaskyte, 2004), and the impact of servant leadership on organizational commitment and organizational citizenship behavior in Italian profits and NPOs (Bobbio et al., 2012).

Regardless of the numerous empirical studies in the field of leaders-followers' work-related attitudes and behaviors in the private sector, several suggestions have been made in various studies for further investigations on the crucial role of leadership in the leader-follower interactions in NPOs (Hailey, 2006; Park et al., 2018; Rowlod and Rohman, 2009). With several studies conducted on the relationship between leadership styles and employees' work outcomes (e.g. Aboramadan et al., 2020; Cicero et al., 2007, 2010; Cicero and Pierro, 2007; Gatti et al., 2017; Quintana et al., 2015; Sarti, 2014; Spitzbart, 2013), insufficient empirical support is still present regarding the consequences of the leaders-followers relationship in the nonprofit context. There is also an inadequate insight into the effects of leadership on employees' workrelated outcomes in NPOs (Park et al., 2018). Therefore, further empirical studies are required to examine the role of leadership in stimulating employees' behaviors and attitudes. 
Overall, although the role of work engagement has been explored in the business research, it has not been adequately addressed as an intervening mechanism leadership and employee outcomes in NPOs (Park et al., 2018). In the context of NPOs, this study aims to investigate the impacts of leadership styles, namely transactional and transformational leadership, on employee's affective commitment and OCB within these organizations. This article provides several insights on the importance of work engagement as an intervening mechanism in the outcomes of the leaders-employees relationship.

\section{Theory and hypotheses development}

\subsection{Leadership styles}

Leadership style is perceived as a pattern of influencing individuals' behaviors (Zigarmi et al., 2004). Different leadership styles have been investigated in previous literature, and it was found in Woods and King's (2012) study that transformational and transactional leadership were the most studied leadership styles. To be specific, transformational leaders refer to the leaders who are followed by their subordinates to achieve the organization objectives, and this phenomenon is indicated through the subordinates' trust and respect for the leader (Bass, 1985). Meanwhile, it has been agreed that transformational leadership is composed of several elements, namely charisma, inspirational motivation, intellectual stimulation, individualized consideration and personal recognition.

Charisma is known as a category of personality traits, which lead to the influence of the leaders on the individuals' behaviors and feelings (Riggio, 2009). This element has been viewed as an important variable in generating respect and trust (Bealer and Bhanugopan, 2014). Meanwhile, inspirational motivation refers to the leaders' ability to articulate a compelling vision for their followers (Bass, 1985), instill confidence in the followers, and inspire them (Bass and Bass, 2008). Furthermore, intellectual stimulation refers to the extent to which the leaders enhance their followers' ability and skills to think and analyze problems (Bass, 1985). As the fourth component of transformation leadership, individualized consideration emphasizes on the role of the leaders in coaching and mentoring their followers for the aim of releasing their potential through learning opportunities (Avolio et al., 1999; Bass and Riggio, 2006). On the other hand, personal recognition focuses on the leaders' appreciation of employees' achievements and the provision of rewards to the deserving employees (Rafferty and Griffin, 2004).

Empirical evidence demonstrates the benefits contributed by transformational leadership to the organization and the members. It was found in previous studies that transformational leadership was a significant predictor of organizational citizenship behavior (Hassi, 2018), high performance (Jing, 2018), job satisfaction (Aydogmus et al., 2018; Spitzbart, 2013), affective commitment (Lee, 2005), generating profits (Brandt et al., 2016), trust in leaders (Holtz and Harold, 2008), motivation (Charbonneau et al., 2001), team learning (Bucic et al., 2010) and innovation (Boerner et al., 2007).

On another note, the idea of transactional leadership is that the leader sets the work guidelines to be followed by the employees (Bass, 1985; Kanungo, 2001). Therefore, this type of leadership is more associated with maintaining the flow of the operations inside the organization. Transactional leaders are also responsible for setting objectives, determining the requirements of the task, and defining roles to encourage subordinates' loyalty, reduce their resistance and promote achievements based on rewards (Deichmann and Stam, 2015).

The transactional leadership style consists of two dimensions, namely contingent rewards and management by exception. Specifically, the contingent reward is mainly based on the assumption that leaders identify the tasks together with the expected rewards to be obtained by employees on their achievements (Antonakis et al., 2003). In this case, there exists an agreement between the leader and the followers based on the motivation regarding the rewards and sanctions. In other words, transactional leaders provide rewards as the targets
Leadership styles in nonprofit organizations 
$\mathrm{JMD}$ $39,7 / 8$

to be achieved by the employees. In the case of management by exception, leaders oversee followers' performance and take corrective actions during the occurrence of major deviations from the plan (Slocum and Hellriegel, 2007). The leadership literature provides support regarding the relationship between transactional leadership and job satisfaction (Clabaugh et al., 2000; Epitropaki and Martin, 2005; Spitzbart, 2013), organizational commitment (Jabeen et al., 2015) and organizational effectiveness (Bass and Riggio, 2006).

Finally, our theoretical support for the links between transformational-transactional leadership and employees' attitudes and behaviors is well-rooted in social exchange theory (Blau, 1964). Building on this theory, we can argue that there is a sort of reciprocation between the leader and the followers.

For instance, if followers perceive the transformational leader as motivating and personally recognizing their abilities, they are more likely to reciprocate by displaying positive attitudes and behaviors. Similarly, if followers perceive their transactional leader as fair, they will be motivated to pay back by demonstrating positive work-related attitudes and behaviors.

\subsection{A closer look into leadership research in NPOs}

Leadership in NPOs as a research topic has gained significant interest from academics and researchers due to the continuous change and challenges faced by these organizations. In the era of limited financial and human resources, including the constantly changing work environment, the leaders in NPOs have to exercise their roles in creative and innovative manners to achieve the organization's objectives (Golensky, 2011).

In general, employees in NPOs are not properly remunerated compared to their counterparts in business companies and governments (Bittschi et al., 2015). As a result, the employees' perceptions of being appreciated would be distorted, resulting in lower engagement in work (Hulkko-Nyman et al., 2012). Therefore, leaders in NPOs play a significant role in ensuring positive workplace outcomes due to the continuous efforts of these organizations to enhance employee's commitment (Vecina et al., 2013), work engagement (Park et al., 2018) and performance (Erdurmazli, 2019).

Empirically, the research of leadership in NPOs has flourished in the last decade in different geographical parts of the world. Among the topics investigated in previous research is the role of leadership in enhancing employees' attitudes and behaviors, and the impact of leadership on organizational effectiveness, performance and innovativeness. For illustration, in a study by Mitchell (2015) on the relationship between leadership values and the reputation of organizational effectiveness in US NGOs, it was found that NGOs led by leaders who possessed dedication, professionalism and diverse working strategies demonstrated higher levels of a reputation for effectiveness. Another study in the US context by Jaskyte (2004) revealed that transformational leadership was a significant predictor of organizational culture due to its positive implications for innovativeness in NPOs. Meanwhile, Reed and Ferrari (2017) found that transformational leadership of deacons was service-oriented, with a focus placed on the overall health of the organization. A study was also conducted by Allen et al. (2018) on the impacts of servant leadership on organizational commitment via structural empowerment in a US nonprofit organization, and it was found that structural empowerment had a significant mediating effect on the relationship between servant leadership and organizational commitment. On the other hand, Brimhall (2019) found a positive relationship between transformational leaders' behaviors and the perceptions of inclusion, which influenced organizational commitment and perceived group performance.

In Europe, various studies were conducted in the leadership research in NPOs, such as the study by Benevene et al. (2018), which found a positive relationship between ethical leadership and Italian volunteers' intention to remain and affective commitment. Two other studies in Italy found that participative and instrumental styles of leadership were positively related to the vigor component of work engagement in human services organizations 
(Sarti, 2014), while servant leadership was a significant determinant of extra-role behaviors and organizational commitment (Bobbio et al., 2012). In a study conducted by Megheirkouni (2016) in the UK, it was found that management by the exception of transactional leaders and idealized behaviors of transformational leaders were essential in upgrading the organizational learning in British nonprofit sports. Meanwhile, a study by Rowold and Rohman (2009) in Germany found that both transformational-transactional leadership and positive emotions were positively associated among the musicians in German Orchestras. Moreover, it was found by Rowold et al. (2014) that LMX was the most important variable in explaining job satisfaction, while transformational leadership was a determinant of organizational commitment in German NPOs.

In other parts of the world, transformational leadership was found to mediate the relationship between project success and project managers' characteristics in Pakistani NPOs (Hassan et al., 2017), while the relationship between transformational leadership and job satisfaction was fully mediated by trust and self-efficacy in a nonprofit organization of higher education in Turkey (Y1ldız and Şimşek, 2016). In the case of NPOs in India, transformational leadership was shown to have an indirect influence on organizational effectiveness by promoting organizational culture (Shiva and Suar, 2012).

The above review of the leadership-followers research in NPOs shows that the role of work engagement as an intervening variable between leadership and employees' outcomes has not yet been examined and needs further examination in the nonprofit research. This was supported by Bakker and Albrecht (2018) in their recent review, which suggested the need to examine the antecedents and outcomes of work engagement in sectors like the nonprofit one.

\subsection{Leadership and affective commitment}

Affective commitment is defined as an individual's emotional attachment to the organization, involvement and identification with the organization (Allen and Meyer, 1990; Meyer and Herscovitch, 2001). Employees with high levels of affective commitment have a higher possibility of remaining in the organization due to their less intention to quit (Meyer and Allen, 1991). Furthermore, being the most notable factor of other behaviors (Lavelle et al., 2007), affective commitment provides a highly accurate explanation of organizational commitment (Sabella et al., 2016). More specifically, an affective commitment was found to positively influence job-related behaviors and attitudes, such as job satisfaction (Marcovitz et al., 2007) and organizational citizenship behavior (Liu, 2009).

Leadership was found to play a significant role in enhancing organizational commitment (Dick, 2011; Jackson et al., 2013; Kim, 2012). To illustrate, transformational leaders are capable of influencing their subordinates' affective commitment by strengthening their intrinsic motivation, linking their efforts with goals attainment and enhancing their personal commitment to the vision of the organization (Avolio et al., 2004). In other words, transformational leaders motivate their followers to display a high performance (Avolio et al., 1999), encourage the followers to look past their interests, and concentrate on the general interest of the organization (Bass and Avolio, 1997). As a result, a favorable climate could be created, which aligned followers' values with the objectives and values of the organization.

The relationship between transformational leadership and affective commitment was empirically established by several studies in the business contexts (e.g. Bass and Riggio, 2006; Kim, 2014; Koh et al., 1995; Lee et al., 2017; Meyer et al., 2002; Walumbwa and Lawler, 2003). It was found by other studies by Walumbwa et al. (2005) in Nigeria, Gillet and Vandenberghe (2014) in France and Kim (2007) in Korea that transformational leadership had a positive effect on the affective commitment. In the case of the relationship between transactional leadership and affective commitment, Kim (2001) and Kim (2007) found that transactional leaders' behaviors were positively related to employees' affective commitment.
Leadership styles in nonprofit organizations 
$\mathrm{JMD}$ $39,7 / 8$

Furthermore, Sayadi (2016) found that high affective commitment among Irani teachers was associated with transactional leadership. Moreover, dimensions of transactional leadership had a significant positive influence on employees' affective commitment (Mesu et al., 2012). Based on the aforementioned arguments, the following hypotheses were developed in this study:

H1. Transformational leadership has a positive influence on employees' affective commitment in NPOs.

H2. Transactional leadership has a positive influence on employees' affective commitment in NPOs.

\subsection{Leadership and organizational citizenship behavior}

Organizational citizenship behavior (OCB) refers to the extra-role actions performed by employees beyond their work, which contribute to the organization's development (Organ, 1997). These actions are not necessarily recognized by the rewarding scheme in the organization (Podsakoff et al., 2000) as they are the voluntary acts demonstrated by employees at their own will (Humphrey, 2012). Notably, OCB contributes to reinforced and maintained psychological and social work, which supports the employees' job performance (Organ, 1997). Moreover, OCB was found to be beneficial in building social capital and improving the overall effectiveness of the organization (Bolino et al., 2002; Nielsen et al., 2012; Podsakoff et al., 2014).

It was theorized that transformational leadership plays a significant role in promoting $\mathrm{OCB}$, allowing transformational leaders to motivate their subordinates to perform beyond their jobs and to challenge work complexities (Bass and Avolio, 1990). This implies that transformational leaders can expand employees' willingness to get involved in extra-role performance, enhancing the OCB (Podsakoff et al., 1990). In this case, transformational leaders could influence the employees to perceive their jobs as more challenging and meaningful to influence their level of engagement in OCB (Boerner et al., 2008). It should be noted that although several studies in diverse contexts found that transformational leadership influenced OCB (e.g. Abu Nasra and Heilbrunn, 2015; Carter et al., 2014; Jha, 2014; Khalili, 2017; MacKenzie et al., 2001; Nguni et al., 2006; Podsakoff et al., 1990; Purvanova et al., 2006; Wang et al., 2011), the empirical support on the effects of transformational leadership and OCB in NPOs, were not thoroughly established.

On the other hand, it could be seen that transactional leadership plays a significant role in promoting OCB. The contingent reward behaviors are possibly linked to the followers' OCB as the followers' decision to engage in OCB acts relies mainly on their belief about potential incentives and rewards (Barbuto and Story, 2011). Therefore, followers need to act within the system of rewards and sanctions. Provided that transactional leadership mainly aims to create economic exchange-based relationships (Whittington et al., 2009) based on clear performance standards, the extra-role behaviors will be rewarded by the transactional leaders as far as the behaviors support the leader's standpoint. Empirically, some studies found a positive link between the dimension of rewards contingent and OCB (Barbuto and Story, 2011; Piccolo and Colquitt, 2006) and between management by exception and OCB (Nahum-Shani and Somech, 2011). Based on the previous discussion, the following hypotheses were formulated in this study:

H3. Transformational leadership has a positive influence on employees' OCB in NPOs.

H4. Transactional leadership has a positive influence on employees' OCB in NPOs

\subsection{The role of work engagement}

Two decades ago, the notion of work engagement received attention from several scholars and practitioners (Aboramadan et al., 2020; Aboramadan et al., 2019; Wollard and Shuck, 2011). According to Bakker et al. (2008), work engagement defines the level of motivation and positive 
connection of an individual to his work. It has often been conceptualized into three dimensions, namely vigor, dedication and absorption, as suggested by Schaufeli et al. (2002). Provided that an employee who is engaged in his work demonstrates high energy, sense of achievement at work, and engagement in work experiences, it could be seen that engagement represents an energetic and positive state of the employee at work. It was proven in the academic research of organizational behavior that engagement was associated with lower turnover, higher productivity, increased levels of organizational commitment, and improved job performance (Rana et al., 2014; Schaufeli et al., 2002) and higher engagement was found to significantly improve employees' mental health (Robertson and Cooper, 2010) and reduce job burnout (Biggs, 2011). In spite of a number of studies that investigated the leadership-engagement relationship in the business sector, there was a limited number of the body of empirical support regarding this relationship in NPOs.

The assumption that transformational leadership plays a vital role in enhancing employee's engagement is well rooted in theory (Breevaart and Bakker, 2018; Bakker et al., 2011; Buckingham and Coffman, 2014; Parker and Griffin, 2011). Moreover, transformational leadership was found to increase employee's motivation due to the significance it holds to the followers (Avolio and Yammarino, 2002). More specifically, transformational leaders place their vision and confidence in their followers' capability to achieve this vision in the future (Seibert et al., 2011), implying that leaders delegate their vision to the followers and encourage their abilities to perform the desired objectives. As a result, the followers' energy and dedication to their work are strengthened. Meanwhile, Dai et al. (2013) argued that through the transformational leadership style, employees are more willing to engage themselves in their work and sacrifice for the general interest of the organization.

Empirical evidence was established in the business literature regarding the relationship between transformational leadership and work engagement. To illustrate, Li et al. (2018) demonstrated a positive relationship between transformational leaders' behaviors and work engagement among Chinese knowledge workers. Similarly, other studies in different contexts supported the hypothesis that transformational leadership and work engagement were significantly linked (e.g. Amor et al., 2020; Ghadi et al., 2013; Hawkes et al., 2017; Hayati et al., 2014; Tims et al., 2011).

Although transformational leadership showed to be a significant predictor of employees' engagement, transactional leadership, on the other hand, may contribute to promoting high levels of engagement. According to Bass and Avolio (1995), the leaders of contingent rewards clearly identify the organization's objectives and communicate their expectations to their subordinates to achieve the goals. This action could motivate employees (Bass, 1985) and increase their engagement regardless of the lack of the inspirational appeal of the leaders, who adopt the transaction style of leadership.

On the relationship between transactional leadership and work engagement, the studies of Breevaart et al. (2014), Judge and Piccolo (2004) and Padmanathan (2010) found a positive relationship between transactional leadership and work engagement.

It could be seen that work engagement could play a mediating role between several job resources and employees' outcomes. To illustrate, Hakanen et al. (2006) found that organizational commitment had a positive association with work engagement, and it mediated the relationship between job resources and organizational commitment. Meanwhile, other studies found that work engagement was a significant mediating variable between transformational leadership and OCB (Purvanova et al., 2006) and between charismatic leadership and work engagement (Babcock-Roberson and Strickland, 2010). Therefore, it is believed that with effective implementation of a leadership style, there would be a higher probability that employees would be engaged in their work, ultimately showing higher levels of dedication and extra-role behaviors. Based on this discussion, the following hypotheses were formulated:
Leadership styles in nonprofit organizations 
$\mathrm{JMD}$

$39,7 / 8$
H5. Work engagement mediates the relationship between (a) transformational leadership and affective commitment and (b) transformational leadership and OCB in NPOs.

H6. Work engagement mediates the relationship between (a) transactional leadership and affective commitment and (b) transactional leadership and OCB in NPOs.

\section{6}

\section{Research method}

This research adopts a quantitative-analytical research design with the aim of proposing a model of the effects of both transformational and transactional leadership on one attitudinal variable (affective commitment) and one behavioral variable $(\mathrm{OCB})$ where work engagement is to be intervening mechanism as presented in Figure 1.

\subsection{Participants and procedures}

Data were collected from staff-level employees with nonexecutive job titles at Italian nonprofit organizations in the north of Italy. The field of work of these organizations is to care for the elderly and disabled people, social development, education and immigration. In this stage, online-based questionnaires were distributed to 1,200 employees via email. As Italian is the main mean of communication used in the Italian workplace, the self-administered questionnaires were translated from English into Italian using the back-translation method (Brislin, 1986). A total of 400 questionnaires were gathered and used for statistical analysis with a response rate of $33.33 \%$, which was acceptable as there was no consensus among social science researchers on the minimum threshold for an acceptable response rate (Fowler, 2013a). Notably, the participation in the study was completely voluntary, and respondents were promised to receive the descriptive statistics of the study to encourage participation.

The average age of the respondents was 38.3 years old, and the majority of the respondents were male $(61.4 \%)$. In the case of the respondents' educational background, $20.5 \%$ of the respondents held a bachelor's degree, $70.5 \%$ held a master's degree, while $8 \%$ had a $\mathrm{PhD}$. As for their working experience, $33.5 \%$ of the respondents had worked for over three years, $60 \%$ had worked for three to seven years and $6.5 \%$ had worked for over seven years. In respect of the respondents' position in the organization, $73 \%$ of the respondents held administrative positions, while $27 \%$ held administrative and project management titles.

Figure 1.

Research model

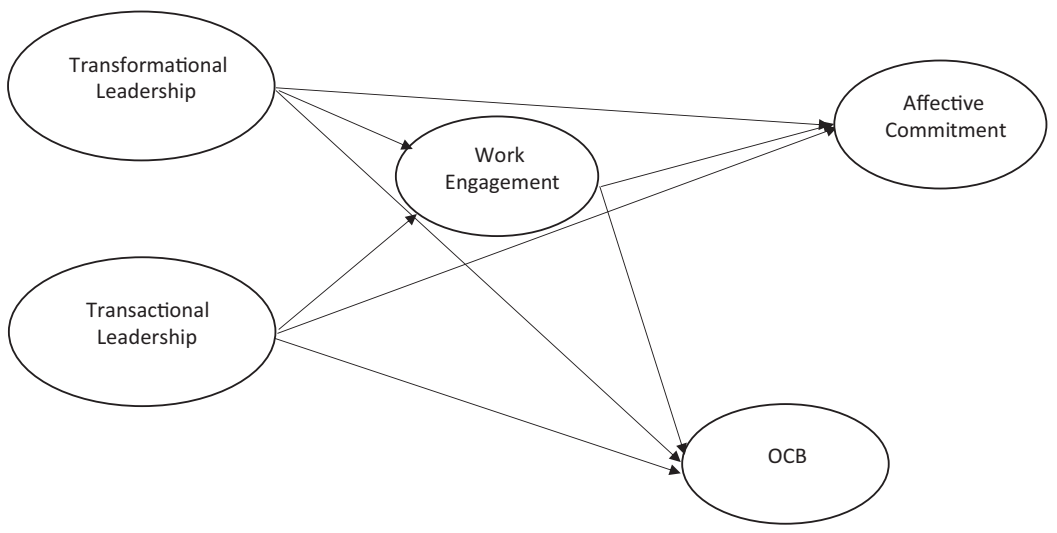




\subsection{Instrumentation}

The online-based questionnaire consisted of three sections, in which the first section covered personal information of the respondents, the second section presented the questions on leadership styles (transformational and transactional leadership), and the third section covered questions on employees' outcomes, including work engagement, OCB and affective commitment. All the variables were measured using 7-point scales ranging from 1 (absolute disagreement) to 7 (absolute agreement).

Transformational and Transactionalleadership: Participants assessed the transformational leadership of their supervisors using three scales of charisma, intellectual stimulation and personal recognition. Both charisma and intellectual stimulation scales were adopted from Bass (1984) while personal recognition was adopted by Rafferty and Griffin (2004) $\left(\mathrm{Chi}^{2} / \mathrm{df}=1.587\right.$; comparative fit index $(\mathrm{CFI})=0.957$; Tucker-Lewis Index $(\mathrm{TLI})=0.953$; and root-mean-square error of approximation (RMSEA) $=0.038$ ). The Cronbach's alpha for transformational leadership amounted to 0.873 .

In assessing transactional leadership, 11 items were used, which consisted of two dimensions of rewards contingent and management by exception borrowed from the Multifactor Leadership Questionnaire by Bass (1985) $\left(\mathrm{Chi}^{2} / \mathrm{df}=1.520\right.$; CFI $=0.962$; TLI $=0.958$; and root mean square error of approximation RMSEA $=0.036$ ). The aforementioned items consisted of namely contingent (seven items) and management by exception (four items). Additionally, the Cronbach's alpha for transactional leadership amounted to 0.846 .

Work engagement: A 9-item scale obtained from the Utrecht Work Engagement Scale by Schaufeli et al. (2006) was used. Accordingly, a sample item used is "when I wake up, I feel going to work," and the Cronbach's alpha for work engagement amounted to 0.814 .

Individual OCB: The assessment of this construct involved the adaption of 6-items withdrawn from the scale developed by Williams and Anderson (1991). A sample item used is "I help my colleagues when their workload is heavy," and the Cronbach's alpha for OCB amounted to 0.761 .

Affective commitment: This was assessed using the 8-item scale developed by Allen and Meyer (1990). A sample item used for this assessment is "I would be very happy to spend the rest of my career with my cooperative," and the Cronbach's alpha for affective commitment amounted to 0.846 .

\section{Analysis strategy}

Using SPSS 22.0 Harman test, correlations, internal consistency values and descriptive statistics were calculated, while AMOS 22.0 was used to check for the measurement model and structural model. Confirmatory factor analysis and structural model were examined using the maximum likelihood method (Anderson and Gerbing, 1988). The following fit indices were used to evaluate the measurement model and structural model; $\mathrm{Chi}^{2} / \mathrm{df}$, TuckerLewis coefficient (TLI), comparative-fit index (CFI) and root mean square error of approximation (RMSEA). Following the method of Preacher and Hayes (2004), mediation analysis was examined, adopting the 5000-sample bootstrapping technique.

\section{Common method bias assessment, reliability, validity and confirmatory factor analysis}

As the data collected in this study originated from a single source and based on the suggestions by Podsakoff et al. (2003), Harman's single factor test was utilized to assess the degree of common method bias. The results of the exploratory factor analysis generated five factors in which the measured variables did not load to a single factor and the general factor 
$\mathrm{JMD}$ $39,7 / 8$

\section{8}

does not explain a majority of variance (32.024\%), which was below the cutoff value of 50 percent. This gives an indication that the data is free of common bias. Therefore, it was indicated that the data were free of common bias. Meanwhile, confirmatory factor analysis was implemented to assess the measures from the independence and distinctiveness perspective. This analysis was conducted, via AMOs 22, for the hypothesized model, resulting in a highly acceptable fit from the fit indices $\left(\mathrm{Chi}^{2} / \mathrm{df}=1.447 ; \mathrm{CFI}=0.966\right.$; TLI $=0.962$; RMSEA $=0.033$ ).

Based on the results of the measurement model, the average variance extracted (AVE) and composite reliability (CR) (Fornell and Larcker, 1981), were used to ensure the validity and reliability of the instrument. It could be seen from the results in Table 1 that the AVEs of all the measures were higher than 0.50, while all the CRs of all the measures exceeded 0.70 (Fornell and Larcker, 1981). Overall, the loadings for all the items exceeded 0.7, as per the rule by Hair et al. (2016). Therefore, the convergent validity of all the measures was confirmed from the results.

\section{Results}

Table 2 presents the descriptive statistics for the research variables, which included the minimum and maximum statistics, mean, standard deviation and correlations among all the variables in this study. The values of minimum, maximum, mean and standard deviations for transformational leadership amounted to $3.33,6.75,5.249$ and 0.620 , respectively, while the values of minimum, maximum, mean and standard deviations amounted to $3.25,6.88,5.17$ and 0.643 , respectively. As for work engagement, the values of minimum, maximum, mean and standard deviations amounted to $3.25,6.75,5.39$ and 0.731 , respectively, while the values of minimum, maximum, mean and standard deviations for OCB amounted to 1.67, 6.67, 4.65 and 0.824 , respectively. The values of minimum, maximum, mean and standard deviations for affective commitment amounted to 2.80, 6.60, 5.13 and 0.745, respectively (see Table 2).

Positive correlations were found between two styles of leadership, work engagement, OCB and affective commitment. The examples of these correlations included transformational leadership and work engagement $(r=0.479, p=0.000)$, transformational leadership and OCB $(r=0.443, p=0.000)$ and transformational leadership and affective commitment $(r=0.506$, $p=0.000)$. Other significant correlations were found between transactional leadership and work engagement $(r=0.448, p=0.000)$, transactional leadership and OCB $(r=0.439$, $p=0.000)$ and transactional leadership and affective commitment $(r=0.442, p=0.000)$.

\subsection{Hypothesis testing}

To verify the hypotheses between the studied variables proposed in this study, AMOs 22 was utilized, and two structural equations were developed. In the first structural model of this study, the mediating variable was excluded to observe the effects of independent variables on

\begin{tabular}{lcc}
\hline & Composite reliability (CR) & Average variance extracted (AVE) \\
\hline (TFL) & 0.725 & 0.603 \\
$(\mathrm{TSL})$ & 0.820 & 0.569 \\
$(\mathrm{WE})$ & 0.817 & 0.529 \\
$(\mathrm{OCB})$ & 0.768 & 0.527 \\
$(\mathrm{AC})$ & 0.850 & 0.533 \\
Note(s): (TFL): Transformational Leaderships, (TSL): Transactional Leadership, (WE): Work Engagement, \\
(OCB): Organizational Citizenship Behavior, (AC): Affective commitment
\end{tabular}

Table 1.

AVEs and CRs

(OCB): Organizational Citizenship Behavior, (AC): Affective commitment 


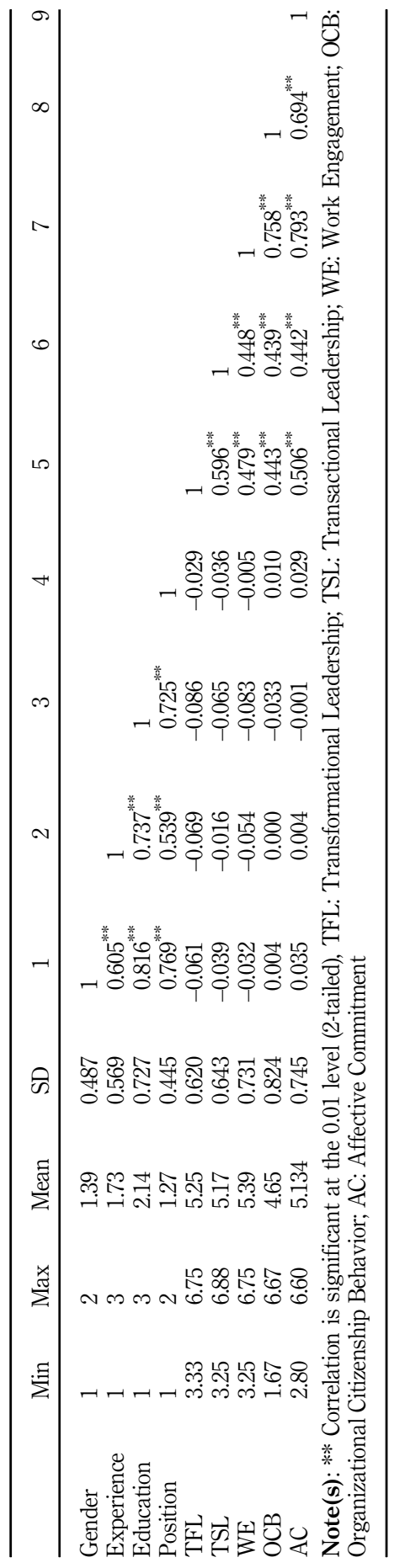

\section{Leadership styles in nonprofit organizations \\ 879}

Table 2. Descriptive statistics and Pearson correlations 
$\mathrm{JMD}$ $39,7 / 8$

880 the dependent variables. As a result, a good fit of data was obtained from the structural equation $\left(\mathrm{Chi}^{2} / \mathrm{df}=1.773\right.$; $\mathrm{CFI}=0.946$; $\mathrm{TLI}=0.941$; $\left.\mathrm{RMSEA}=0.044\right)$.

Based on the results of model 1 presented in Figure 2, it was indicated from the standardized coefficients that transformational leadership was a significant predictor of affective commitment $(\beta=0.385, p=0.000)$, and transformational leadership had a significant positive effect on OCB $(\beta=0.272, p=0.000)$. Similarly, transactional leadership was found to have a significant positive effect on affective commitment $(\beta=0.775, p=0.000)$ and $\operatorname{OCB}(\beta=0.895, p=0.000)$. Overall, the results of this study supported H1, H2, H3 and H4.

Meanwhile, to verify the mediating hypothesis $\mathrm{H} 5$ and $\mathrm{H} 6$, a second structural equation model was developed including the mediator (work engagement). As a result, a good fit of the data was obtained from the modification indices $\left(\mathrm{CMIN}^{2} / \mathrm{df}=1.776\right.$; $\mathrm{CFI}=0.940$; $\mathrm{TLI}=0.935$; RMSEA $=0.044$ ). The results in Table 3 demonstrated the direct and indirect effects of the partial mediation structural equation model. The indirect effects of work engagement were significant between transformational leadership and affective commitment $(\beta=0.368, p=0.000)$, transformational leadership and OCB $(\beta=0.387, p=0.000)$, transactional leadership and affective commitment $(\beta=0.349, p=0.000)$, and transactional leadership and $\operatorname{OCB}(\beta=0.368, p=0.000)$. To determine the type of the mediation, we need to look at the significance of the direct effects with the presence of the mediator following the

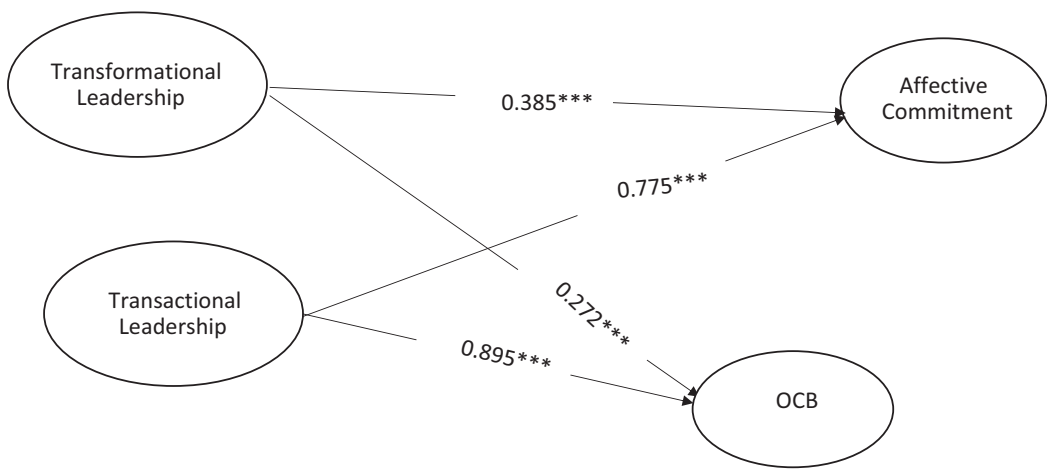

Note(s): *** Significant at 0.001
Figure 2.

Standardized Path Coefficients (Model 1)
Standardized coefficients of Partially mediated SEM model)
Path (direct effects)

Standardized coefficients

$$
\begin{aligned}
& \text { WE }<- \text { TFL } \\
& \mathrm{OCB}<- \text { TFL } \\
& \mathrm{AC}<- \text { TFL } \\
& \mathrm{WE}<- \text { TSL } \\
& \mathrm{OCB}<- \text { TSL } \\
& \mathrm{AC}<- \text { TSL } \\
& \mathrm{OCB}<- \text { WE } \\
& \mathrm{AC}<- \text { WE }
\end{aligned}
$$

Indirect Effects

$\mathrm{OCB}<-$ WE $<$-TFL

$\mathrm{AC}<-\mathrm{WE}<-$ TFL

$\mathrm{OCB}<-$ WE $<-$ TSL

$\mathrm{AC}<-\mathrm{WE}<-\mathrm{TSL}$

$0.429 * * *$

0.004

$0.134^{* * *}$

$0.408^{* * * *}$

0.076

$-0.007$

$0.901^{* * *}$

$0.856^{* * * *}$

Standardized coefficients

$0.387^{* * * *}$

$0.368^{* * * *}$

$0.368^{* * * *}$

$0.349 * * *$

Note(s): $* * *$ sig at $0.001, * *$ sig at 0.05 
suggestions of Hair et al. (2016). The direct effects of transformational leadership on $\mathrm{OCB}(\beta=$ $0.004, p>0.05)$, transactional leadership on OCB $(\beta=0.076, p>0.05)$, and transactional leadership on affective commitment $(\beta=-0.007, p>0.05)$ were not significant, suggesting a full mediation in the relationship the examined variables. However, only the direct effect of transformational leadership on affective commitment $(\beta=0.429, p=0.000)$ was significant, indicating a partial mediation effect of work engagement on the relationship between these variables.

\section{Discussion}

This research aimed to investigate the impacts of transformational and transactional leadership styles on employees' outcomes in NPOs. The results of this study provided empirical support on the mediating role of work engagement in the relationship between leadership styles and both affective commitment and OCB. Moreover, it was found that transformational leaders' behaviors had a positive effect on the employees' affective commitment, and this result was consistent with the finding in the previous research conducted by Gillet and Vandenberghe (2014), Kim (2007), and Walumbwa et al. (2005), which found a positive relationship between transformational leadership and affective commitment in different cultures. These results could be explained by the fact that transformational supervisors lead their employees to transcend their self-interests for the general interests of the organization (Bass and Avolio, 1997), use vision and mission to allow subordinates to easily identify themselves with the organization (Jackson et al., 2013), and recognize the values of employees (Fairlie, 2011), which would contribute to a sense of commitment among the employees.

It was also found that transformational leadership influenced OCB among employees, which was in line with the findings in previous research, in which the positive effect of transformational leadership on OCB was established (e.g. Abu Nasra and Heilbrunn, 2015; Khalili, 2017; Nguni et al., 2006; Purvanova et al., 2006; Wang et al., 2011). The results suggest that the adoption of transformational leadership behaviors could enhance the involvement of employees into extra-role behaviors (OCB), which transcended their job definitions. Furthermore, it was proven that the use of transactional leadership contributed to an enhanced affective commitment, which suggested that there was a positive relationship between transactional leadership and affective commitment. This finding was also consistent with previous empirical studies (e.g. Kim, 2001; Mesu et al., 2012; Ramezaninezhad et al., 2011; Sayadi, 2016).

Moreover, the result of this study illustrated that transactional leadership influenced OCB among employees, which was in line with the results found in the previous studies by Barbuto and Story (2011), Nahum-Shani and Somech (2011) and Piccolo and Colquitt (2006), which revealed the positive impact of transactional leadership on OCB. Therefore, OCB among employees might be influenced by rewards and punishment tactics, implying that the transactional behaviors of supervisors encourage extra-role behaviors among the employees. Finally, the results revealed that work engagement played a significant partial mediating role in the relationship between transformational leadership and affective commitment. Moreover, work engagement exerted a significant full mediation effect between transformational leadership and $\mathrm{OCB}$, transactional leadership and $\mathrm{OCB}$ and transactional leadership and affective commitment.

These results were in line with the results in previous research, which suggested that work engagement mediated the relationship between job resources and organizational commitment (Hakanen et al., 2006) and the relationship between job resources and OCB (Babcock-Roberson and Strickland, 2010; Purvanova et al., 2006). This implies that with the effective practice of leadership style by the leaders (whether transformational or
Leadership styles in nonprofit organizations

881 
$\mathrm{JMD}$ $39,7 / 8$ transactional), employees would feel more engaged in their jobs, and subsequently show higher levels of commitment and display extra-role behaviors.

\section{Implications}

This study is one of the very few studies that examine the impacts of transactional and transformational leadership on employees' attitudes and behaviors in nonprofits. Previous research has mainly focused on examining each type of different leadership styles separately (Rowold et al., 2014). Therefore, the current study enriches the leadership literature given the scholarly calls to further investigate the topic.

Practically, the results of our study provide insights on how the attitudes and behaviors of employees in nonprofits can be influenced by their leaders' and supervisors' behaviors. Moreover, the study recommends nonprofits to highlight the importance of leadership development in their organizations. Therefore, training programs for leaders could be developed, with the purpose of providing leaders with the right means and tactics to create a work environment where employees feel that their jobs are important to them and they can demonstrate positive work-related outcomes. Still, it is essential that these training programs consider local leadership styles to overcome any potential resistance (Ardichvili, 2001).

Furthermore, our results suggest that the presence of both transactional and transformational leadership is important for work engagement among nonprofits, as leaders can perform well when using both styles (Zigarmi et al., 2004). Every leader needs to use different styles of leadership (Bass and Riggio, 2006). Hence, nonprofits leaders should pay attention to the usefulness and application of both transactional and transformational leadership styles because an effective leader can utilize different leadership strategies to influence others (Yukl, 2010). Building on that, this study can be also useful to different types of nonprofits (civil societies, charities, NGOs, humanitarian organizations) to figure

out the effectiveness of their leadership styles and their influence on the followers. Hence, by affecting employees' attitudes and behaviors, this will ultimately benefit the community and the targeted beneficiary these organizations serve.

Finally, the results of the current study provide insights for nonprofits on the importance of recruiting leaders to improve the organization's performance and fulfill the leaderorganization fit. Hence, nonprofits need to select leaders who are knowledgeable about different leadership styles and their consequences in the workplace. The results recommend nonprofits senior management to enhance their awareness of different leadership styles in order to encourage employees to demonstrate effective behaviors.

\subsection{Limitations and future research}

Our results need to be carefully interpreted, as our research has a number of limitations. The first issue is the research design, which limits the possibility of examining causality among the studied variables. Hence, future studies should consider longitudinal studies to allow for cause-effect assessment (Cohen et al., 2011). Second, the research used Italian nonprofits to investigate the research hypotheses, which might limit the generalizability of the results. Although our results are consistent with previous theoretical and empirical support in leadership literature, the results still need to be replicated using a larger sample from other European contexts. Third, the research relies on data gathered from the same source: an issue, which might introduce a common bias method. Future research might consider collecting data from different sources. Another limitation in our research is the use of the self-response measures, which might introduce the response bias (Podsakoff and Organ, 1986).

Fourth, in our research outcome variables, such as work engagement, were not analyzed in its three dimensions (vigor, dedication and absorption), and hence, future research might 
analyze each of these dimensions as a separate outcome. Fifth, this research investigated work engagement as mediating leadership styles and the dependent variables. Future research should further consider the intervening role of subordinates' job characteristics in the organization (Gillet and Vandenberghe, 2014). Sixth, our research investigated the relationship between study' variables without controlling for the respondents' demographics; therefore, future research should replicate the study in other contexts and control for employees' demographics profile.

Future research should also analyze the effects of the dimensions of both transactional and transformational leadership on work-related outcomes (Hassi, 2018), to examine the predictive power of each of these dimensions. Future studies should also examine other types of leadership (e.g. servant leadership, ethical leadership, participative leadership, etc.) in the nonprofit context and their impacts on work-related attitudes and behaviors. Finally, another potential research endeavor is to replicate the study in both profit and nonprofit sectors to check for any differences between these two contexts.

\section{References}

Aboramadan, M., Hassi, A., Alharazin, H.J., Dahleez, K.A. and Albashiti, B. (2019), "Volunteering drivers and continuation will: the role of engagement", Journal of Management Development, Vol. 38 No. 5, pp. 405-420.

Aboramadan, M., Albashiti, B., Alharazin, H. and Dahleez, K.A. (2020), "Human resources management practices and organizational commitment in higher education: the mediating role of work engagement", International Journal of Educational Management, Vol. 34 No. 1, pp. 154-174.

Abu Nasra, M. and Heilbrunn, S. (2015), "Transformational leadership and organizational citizenship behavior in the Arab educational system in Israel: the impact of trust and job satisfaction", Educational Management Administration and Leadership, SAGE Publications, Vol. 44 No. 3, pp. 380-396.

Alkahtani, A.H. (2015), "The influence of leadership styles on organizational commitment: the moderating effect of emotional intelligence", Business and Management Studies, Vol. 2 No. 1, pp. 23-34.

Allen, N.J. and Meyer, J.P. (1990), "The measurement and antecedents of affective, continuance and normative commitment to the organization", Journal of Occupational Psychology, Wiley Online Library, Vol. 63 No. 1, pp. 1-18.

Allen, S., Winston, B.E., Tatone, G.R. and Crowson, H.M. (2018), "Exploring a model of servant leadership, empowerment, and commitment in nonprofit organizations", Nonprofit Management and Leadership, Wiley Online Library, Vol. 29 No. 1, pp. 123-140.

Amor, M.A., Abeal Vázquez, J.P. and Faíña, J.A. (2020), “Transformational leadership and work engagement: exploring the mediating role of structural empowerment”, European Management Journal, Vol. 38 No. 1, pp. 169-178.

Andersen, J.A. (2016), “An old man and the 'sea of leadership”, Journal of Leadership Studies, Wiley Online Library, Vol. 9 No. 4, pp. 70-81.

Anderson, J.C. and Gerbing, D.W. (1988), "Structural equation modeling in practice: a review and recommended two-step approach”, Psychological Bulletin, Vol. 103 No. 3, pp. 411-423.

Antonakis, J., Avolio, B.J. and Sivasubramaniam, N. (2003), "Context and leadership: an examination of the nine-factor full-range leadership theory using the Multifactor Leadership Questionnaire", The Leadership Quarterly, JAI, Vol. 14 No. 3, pp. 261-295.

Ardichvili, A. (2001), "Leadership styles and work-related values of managers and employees of manufacturing enterprises in post-communist countries", Human Resource Development Quarterly, John Wiley \& Sons, Vol. 12 No. 4, pp. 363-383.

\section{Leadership styles in nonprofit organizations}

883 
$\mathrm{JMD}$ $39,7 / 8$
Avolio, B.J. and Yammarino, F.J. (2002), Transformational and Charismatic Leadership, The Road Ahead, Boston.

Avolio, B.J., Bass, B.M. and Jung, D.I. (1999), "Re-examining the components of transformational and transactional leadership using the Multifactor Leadership", Journal of Occupational and Organizational Psychology, John Wiley \& Sons, (10.1111), Vol. 72 No. 4, pp. 441-462.

Avolio, B.J., Bass, B.M., Walumbwa, F.O. and Zhu, W. (2004), MLQ, Multifactor Leadership Questionnaire: Technical Report, Leader Form, Rater Form, and Scoring Key for MLQ Form $5 x$-Short, 3rd ed., Mind Garden, Redwood City, CA.

Aydogmus, C., Camgoz, S.M., Ergeneli, A. and Ekmekci, O.T. (2018), "Perceptions of transformational leadership and job satisfaction: the roles of personality traits and psychological empowerment", Journal of Management and Organization, Cambridge University Press, Vol. 24 No. 1, pp. 81-107.

Babcock-Roberson, M.E. and Strickland, O.J. (2010), "The relationship between charismatic leadership, work engagement and organizational citizenship behaviors", Journal of Psychology, Vol. 144, No. 3, pp. 313-326.

Bakker, A.B. and Albrecht, S. (2018), "Work engagement: current trends", Career Development International, Emerald Publishing Limited, Vol. 23 No. 1, pp. 4-11.

Bakker, A.B., Schaufeli, W.B., Leiter, M.P. and Taris, T.W. (2008), "Work engagement: an emerging concept in occupational health psychology", Work and Stress, Taylor \& Francis, Vol. 22 No. 3, pp. 187-200.

Bakker, A.B., Albrecht, S.L. and Leiter, M.P. (2011), "Key questions regarding work engagement", European Journal of Work and Organizational Psychology, Taylor \& Francis, Vol. 20 No. 1, pp. 4-28.

Barbuto, J.E. Jr and Story, J.S.P. (2011), "Work motivation and organizational citizenship behaviors", Journal of Leadership Studies, John Wiley \& Sons, Vol. 5 No. 1, pp. 23-34.

Barling, J., Weber, T. and Kelloway, E.K. (1996), "Effects of transformational leadership training on attitudinal and financial outcomes: a field experiment", Journal of Applied Psychology, American Psychological Association, Vol. 81 No. 6, p. 827.

Bass, B.M. (1985), Leadership and Performance beyond Expectations, 1st ed., Free Press, New York.

Bass, B.M. and Avolio, B.J. (1990), "The implications of transactional and transformational leadership for individual, team, and organizational development", Research in Organizational Change and Development, Vol. 4 No. 1, pp. 231-272.

Bass, B.M. and Avolio, B.J. (1993), "Transformational leadership: a response to critiques" in Chemers, M.M. and Ayman, R. (Eds), Leadership Theory and Research: Perspectives and Directions, Academic Press, San Diego, California, pp. 49-80.

Bass, B.M. and Avolio, B.J. (1995), MLQ Multifactor Leadership Questionnaire Technical Report, Center for Leadership Studies, Binghamton University, NY.

Bass, B.M. and Avolio, B.J. (1997), Full Range Leadership Development: Manual for the Multifactor Leadership Questionnaire, Mind Garden, Redwood City, California.

Bass, B.M. and Bass, R. (2008), Handbook of Leadership: Theory, Research, and Application, Free Press, New York.

Bass, B.M. and Riggio, R.E. (2006), Transformational Leadership, 2nd ed., Lawrence Erlbaum Associates Publishers, Mahwah, New Jersey.

Bealer, D. and Bhanugopan, R. (2014), "Transactional and transformational leadership behaviour of expatriate and national managers in the UAE: a cross-cultural comparative analysis", The International Journal of Human Resource Management, Routledge, Vol. 25 No. 2, pp. 293-316.

Benevene, P., Dal Corso, L., De Carlo, A., Falco, A., Carluccio, F. and Vecina, M.L. (2018), "Ethical leadership as antecedent of job satisfaction, affective organizational commitment and intention 
to stay among volunteers of non-profit organizations", Frontiers in Psychology, Frontiers Media SA, Vol. 9 No. 1, pp. 1-17.

Bhal, K.T. and Ansari, M.A. (2007), "Leader-member exchange-subordinate outcomes relationship: role of voice and justice", Leadership and Organization Development Journal, Emerald Group Publishing, Vol. 28 No. 1, pp. 20-35.

Biggs, A.J. (2011), A Longitudinal Evaluation of Strain, Work Engagement, and Intervention Strategies to Address the Health of High-Risk Employees, Griffith University, Queensland.

Birasnav, M. (2014), "Relationship between transformational leadership behaviors and manufacturing strategy", International Journal of Organizational Analysis, Emerald Group Publishing, Vol. 22 No. 2, pp. 205-223.

Bittschi, B., Pennerstorfer, A. and Schneider, U. (2015), "Paid and unpaid labour in non-profit organizations: does the substitution effect exist?”, British Journal of Industrial Relations, Wiley Online Library, Vol. 53 No. 4, pp. 789-815.

Blau, P.M. (1964), Exchange and Power in Social Life, 1st ed., Wiley, New York.

Bobbio, A., van Dierendonck, D. and Manganelli, A.M. (2012), "Servant leadership in Italy and its relation to organizational variables", Leadership, Vol. 8 No. 3, pp. 229-243.

Boehm, S.A., Dwertmann, D.J.G., Bruch, H. and Shamir, B. (2015), "The missing link? Investigating organizational identity strength and transformational leadership climate as mechanisms that connect CEO charisma with firm performance", The Leadership Quarterly, Elsevier, Vol. 26 No. 2, pp. 156-171.

Boerner, S., Eisenbeiss, S.A. and Griesser, D. (2007), "Follower behavior and organizational performance: the impact of transformational leaders", Journal of Leadership and Organizational Studies, Sage Publications Sage CA, Los Angeles, CA, Vol. 13 No. 3, pp. 15-26.

Boerner, S., Dütschke, E. and Wied, S. (2008), "Charismatic leadership and organizational citizenship behaviour: examining the role of stressors and strain", Human Resource Development International, Routledge, Vol. 11 No. 5, pp. 507-521.

Bolino, M.C., Turnley, W.H. and Bloodgood, J.M. (2002), "Citizenship behavior and the creation of social capital in organizations", Academy of Management Review, Academy of Management, Vol. 27 No. 4, pp. 505-522.

Bono, J.E. and Judge, T.A. (2003), "Self-concordance at work: toward understanding the motivational effects of transformational leaders", Academy of Management Journal, Academy of Management, Vol. 46 No. 5, pp. 554-571.

Brandt, T., Laitinen, E.K. and Laitinen, T. (2016), "The effect of transformational leadership on the profitability of Finnish firms", International Journal of Organizational Analysis, Emerald Group Publishing, Vol. 24 No. 1, pp. 81-106.

Breevaart, K. and Bakker, A.B. (2018), "Daily job demands and employee work engagement: the role of daily transformational leadership behavior", Journal of Occupational Health Psychology, Educational Publishing Foundation, Vol. 23 No. 3, pp. 338-349.

Breevaart, K., Bakker, A., Hetland, J., Demerouti, E., Olsen, O.K. and Espevik, R. (2014), "Daily transactional and transformational leadership and daily employee engagement", Journal of Occupational and Organizational Psychology, John Wiley \& Sons, (10.1111), Vol. 87 No. 1, pp. 138-157.

Brimhall, K.C. (2019), "Inclusion and commitment as key pathways between leadership and nonprofit performance", Nonprofit Management and Leadership, Wiley Online Library, Vol. 30 No. 1, pp. 31-49.

Brislin, R.W. (1986), The Wording and Translation of Research instruments.”, Field Methods in CrossCultural Research, Sage Publications, Thousand Oaks, CA, pp. 137-164.

Bucic, T., Robinson, L. and Ramburuth, P. (2010), "Effects of leadership style on team learning", Journal of Workplace Learning, Vol. 22 No. 4, pp. 228-248.
Leadership styles in nonprofit organizations 
$\mathrm{JMD}$ $39,7 / 8$

Buckingham, M. and Coffman, C. (2014), "First, break all the rules: what the world's greatest managers do differently", Gallup Press, available at: https://books.google.com.om/books? $\mathrm{id}=$ mo67BwAAQBAJ.

Carter, M.Z., Mossholder, K.W., Feild, H.S. and Armenakis, A.A. (2014), "Transformational leadership, interactional justice, and organizational citizenship behavior: the effects of racial and gender dissimilarity between supervisors and subordinates", Group and Organization Management, SAGE Publications, Vol. 39 No. 6, pp. 691-719.

Chandra, T. and Priyono. (2016), "The influence of leadership styles, work environment and job satisfaction of employee performance-studies in the school of SMPN 10 Surabaya", International Education Studies, ERIC, Vol. 9 No. 1, pp. 131-140.

Charbonneau, D., Barling, J. and Kelloway, E.K. (2001), "Transformational leadership and sports performance: the mediating role of intrinsic motivation 1", Journal of Applied Social Psychology, Wiley Online Library, Vol. 31 No. 7, pp. 1521-1534.

Cicero, L. and Pierro, A. (2007), "Charismatic leadership and organizational outcomes: the mediating role of employees' workgroup identification", International Journal of Psychology, Routledge, Vol. 42 No. 5, pp. 297-306.

Cicero, L., Pierro, A. and van Knippenberg, D. (2007), "Leader group prototypicality and job satisfaction: the moderating role of job stress and team identification", Group Dynamics: Theory, Research, and Practice, Educational Publishing Foundation, Cicero, Lavinia, Dipartimento di Psicologia dei Processi di Sviluppo e Socializzazione, University of Rome “La Sapienza”, Via dei Marsi 78, Rome, Italy, 00185, lavinia.cicero@uniroma1.it, Vol. 11 No. 3, pp. 165-175.

Cicero, L., Pierro, A. and Van Knippenberg, D. (2010), "Leadership and uncertainty: how role ambiguity affects the relationship between leader group prototypicality and leadership effectiveness", British Journal of Management, John Wiley \& Sons, (10.1111), Vol. 21 No. 2, pp. 411-421.

Clabaugh, C.A., Monroe, G.S. and Soutar, G.N. (2000), "Supervisory factors affecting job satisfaction in public accounting firms", Australian Accounting Review, John Wiley \& Sons, (10.1111), Vol. 10 No. 20 , pp. $65-72$.

Clawson, J.G.S. (2008), "Leadership as managing energy", International Journal of Organizational Analysis, Emerald Group Publishing, Vol. 16 No. 3, pp. 174-181.

Cohen, L., Manion, L. and Morrison, K. (2011), Research Methods in Education, 7th ed., London, Routledge, doi: 10.4324/9781315456539-38.

Cornforth, C. (2014), "Understanding and combating mission drift in social enterprises", Social Enterprise Journal, Emerald Group Publishing Limited, Vol. 10 No. 1, pp. 3-20.

Dai, Y.-D., Wu, H.-C. and Chen, K.-Y. (2013), "Transformational vs transactional leadership: which is better?: a study on employees of international tourist hotels in Taipei City", International Journal of Contemporary Hospitality Management, Emerald, Vol. 25 No. 5, pp. 760-778.

Deichmann, D. and Stam, D. (2015), "Leveraging transformational and transactional leadership to cultivate the generation of organization-focused ideas", The Leadership Quarterly, Elsevier, Vol. 26 No. 2, pp. 204-219.

Dick, G.P.M. (2011), "The influence of managerial and job variables on organizational commitment", The Police", Public Administration, John Wiley \& Sons, (10.1111), Vol. 89 No. 2, pp. 557-576.

Epitropaki, O. and Martin, R. (2005), "From ideal to real: a longitudinal study of the role of implicit leadership theories on leader-member exchanges and employee outcomes", Journal of Applied Psychology, American Psychological Association, Epitropaki, Olga, Athens Laboratory of Business Administration, Athinas and 2A Areos Street, Vouliagmeni 166 71, Athens, Greece, oepitrop@alba.edu.gr. 
Erdurmazli, E. (2019), "Satisfaction and commitment in voluntary organizations: a cultural analysis along with servant leadership", Voluntas: International Journal of Voluntary and Nonprofit Organizations, Vol. 30 No. 1, pp. 129-146.

Fairlie, P. (2011), "Meaningful work, employee engagement, and other key employee outcomes: implications for human resource development”, Advances in Developing Human Resources, SAGE Publications, Vol. 13 No. 4, pp. 508-525.

Fornell, C. and Larcker, D.F. (1981), "Evaluating structural equation models with unobservable variables and measurement error", Journal of Marketing Research, Vol. 18 No. 1, pp. 39-50.

Fowler, F.J. (2013b), Survey Research Methods, 5th ed., Sage Publications, California.

Fowler, A. (2013a), Striking a Balance: A Guide to Enhancing the Effectiveness of NGOs in International Development, 1st ed., Routledge, London.

Gatti, P., Ghislieri, C. and Cortese, C.G. (2017), "Relationships between followers' behaviors and job satisfaction in a sample of nurses", PLOS ONE, Public Library of Science, Vol. 12 No. 10, p. e0185905.

Ghadi, M.Y., Fernando, M. and Caputi, P. (2013), "Transformational leadership and work engagement: the mediating effect of meaning in work", Leadership and Organization Development Journal, Emerald, Vol. 34 No. 6, pp. 532-550.

Gibson, J.L., Donnelly, J.H. and Ivancevich, J.M. (1991), “Organizations: Behaviour, Structure, Processes", Business Publications, Plano, TX.

Gillet, N. and Vandenberghe, C. (2014), "Transformational leadership and organizational commitment: the mediating role of job characteristics", Human Resource Development Quarterly, John Wiley \& Sons, Vol. 25 No. 3, pp. 321-347.

Golensky, M. (2011), Strategic Leadership and Management in Nonprofit Organizations: Theory and Practice, 1st ed., Oxford University Press, Madison Ave, New York, NY.

Haghighi, F.B. and Maleki, Z.V. (2016), "The relationship between transformational leadership style and behavior of organizational citizen (case study: ghavamin bank)", International Journal of Learning and Development, Vol. 6 No. 3, pp. 80-91.

Hailey, J. (2006), NGO Leadership Development, Praxis paper 10, INTRAC, Oxford.

Hair, J.F., Hult, G.T.M., Ringle, C. and Sarstedt, M. (2016), A Primer on Partial Least Squares Structural Equation Modeling (PLS-SEM), 2nd ed., Sage Publications, Thousand Oaks, California.

Hakanen, J., Bakker, A.B. and Schaufeli, W.B. (2006), "Burnout and work engagement among teachers", The Journal of School Psychology, Vol. 43, pp. 495-513.

Hassan, M.M., Bashir, S. and Abbas, S.M. (2017), "The impact of project managers' personality on project success in NGOs: the mediating role of transformational leadership", Project Management Journal, SAGE Publications Sage CA, Los Angeles, CA, Vol. 48 No. 2, pp. 74-87.

Hassi, A. (2018), "You get what you appreciate' Effects of leadership on job satisfaction, affective commitment and organisational citizenship behaviour", International Journal of Organizational Analysis, Emerald Publishing, Earlycite.

Hawkes, A.J., Biggs, A. and Hegerty, E. (2017), "Work engagement: investigating the role of transformational leadership, job resources, and recovery", The Journal of Psychology, Routledge, Vol. 151 No. 6, pp. 509-531.

Hayati, D., Charkhabi, M. and Naami, A. (2014), "The relationship between transformational leadership and work engagement in governmental hospitals nurses: a survey study", SpringerPlus, Vol. 3 No. 1, p. 25.

Hentrich, S., Zimber, A., Garbade, S.F., Gregersen, S., Nienhaus, A. and Petermann, F. (2017), "Relationships between transformational leadership and health: the mediating role of perceived job demands and occupational self-efficacy", International Journal of Stress Management, Educational Publishing Foundation, Vol. 24 No. 1, p. 34. 
$\mathrm{JMD}$ $39,7 / 8$

Holtz, B.C. and Harold, C.M. (2008), "When your boss says no! the effects of leadership style and trust on employee reactions to managerial explanations", Journal of Occupational and Organizational Psychology, Wiley Online Library, Vol. 81 No. 4, pp. 777-802.

Hulkko-Nyman, K., Sarti, D., Hakonen, A. and Sweins, C. (2012), "Total rewards perceptions and work engagement in elder-care organizations: findings from Finland and Italy", International Studies of Management \& Organization, Taylor \& Francis, Vol. 42 No. 1, pp. 24-49.

Humphrey, A. (2012), "Transformational leadership and organizational citizenship behaviors: the role of organizational identification", The Psychologist-Manager Journal, Routledge, Vol. 15 No. 4, pp. 247-268.

Jabeen, F., Behery, M. and Abu Elanain, H. (2015), "Examining the relationship between the psychological contract and organisational commitment: the mediating effect of transactional leadership in the UAE context", International Journal of Organizational Analysis, Emerald, Vol. 23 No. 1, pp. 102-122.

Jackson, T.A., Meyer, J.P. and Wang, X.-H. (2013), "Leadership, commitment, and culture: a metaanalysis", Journal of Leadership and Organizational Studies, Sage Publications Sage CA, Los Angeles, CA, Vol. 20 No. 1, pp. 84-106.

Jaskyte, K. (2004), "Transformational leadership, organizational culture, and innovativeness in nonprofit organizations", Nonprofit Management and Leadership, Vol. 15 No. 2, pp. 153-168.

Jha, S. (2014), "Transformational leadership and psychological empowerment: determinants of organizational citizenship behavior", South Asian Journal of Global Business Research, Emerald, Vol. 3 No. 1, pp. 18-35.

Jing, F.F. (2018), "Leadership paradigms and performance in small service firms", Journal of Management and Organization, Cambridge University Press, Vol. 24 No. 3, pp. 339-358.

Judge, T.A. and Piccolo, R.F. (2004), "Transformational and transactional leadership: a meta-analytic test of their relative validity", Journal of Applied Psychology, American Psychological Association, Judge, Timothy A, Department of Management, Warrington College of Business, University of Florida, P.O. Box 117165, Gainesville, FL, tjudge@ufl.edu, pp. 32611-7165.

Kanungo, R.N. (2001), "Ethical values of transactional and transformational leaders", Canadian Journal of Administrative Sciences - Revue Canadienne des Sciences de l Administration, Wiley Online Library, Vol. 18 No. 4, pp. 257-265.

Khalili, A. (2017), "Transformational leadership and organizational citizenship behavior: the moderating role of emotional intelligence", Leadership and Organization Development Journal, Emerald, Vol. 38 No. 7, pp. 1004-1015.

Kim, H.J. (2001), "The effects of transformational/transactional leadership on the organizational commitment: a comparison of public and private sector employees", Korean Public Administration Review, Vol. 35 No. 2, pp. 197-216.

Kim, H. (2007), "A study on the causal relationship among organizational culture, leadership, and organizational commitment”, Korean Society and Public Administration, Vol. 18 No. 2, pp. 23-49.

Kim, H. (2012), "Transformational leadership and organisational citizenship behavior in the public sector in South Korea: the mediating role of affective commitment", Local Government Studies, Taylor \& Francis, Vol. 38 No. 6, pp. 867-892.

Kim, H. (2014), "Transformational leadership, organizational clan culture, organizational affective commitment, and organizational citizenship behavior: a case of South Korea's public sector", Public Organization Review, Vol. 14 No. 3, pp. 397-417.

Koh, W.L., Steers, R.M. and Terborg, J.R. (1995), "The effects of transformational leadership on teacher attitudes and student performance in Singapore”, Journal of Organizational Behavior, John Wiley \& Sons, Vol. 16 No. 4, pp. 319-333.

Lavelle, J.J., Rupp, D.E. and Brockner, J. (2007), "Taking a multifoci approach to the study of justice, social exchange, and citizenship behavior: the target similarity model", Journal of Management, Sage Publications Sage CA, Los Angeles, CA, Vol. 33 No. 6, pp. 841-866. 
Le, P.B. and Lei, H. (2017), "How transformational leadership supports knowledge sharing: evidence from Chinese manufacturing and service firms", Chinese Management Studies, Emerald Publishing, Vol. 11 No. 3, pp. 479-497.

Lee, J. (2005), "Effects of leadership and leader-member exchange on commitment", Leadership and Organization Development Journal, Emerald Group Publishing Limited, Vol. 26 No. 8, pp. $655-672$.

Lee, Y.H., Woo, B. and Kim, Y. (2017), "Transformational leadership and organizational citizenship behavior: mediating role of affective commitment", International Journal of Sports Science and Coaching, SAGE Publications, Vol. 13 No. 3, pp. 373-382.

Lewis, D. (2001), Management of Non-governmental Development Organisations: An Introduction, Routledge, London.

Li, Y., Castaño, G., Li, Y., Li, Y. and Li, Y. (2018), "Linking leadership styles to work engagement: the role of psychological capital among Chinese knowledge workers", Chinese Management Studies, Emerald, Vol. 12 No. 2, pp. 433-452.

Liu, Y. (2009), "Perceived organizational support and expatriate organizational citizenship behavior: the mediating role of affective commitment towards the parent company", Personnel Review, Emerald Group Publishing, Vol. 38 No. 3, pp. 307-319.

MacKenzie, S.B., Podsakoff, P.M. and Rich, G.A. (2001), "Transformational and transactional leadership and salesperson performance", Journal of the Academy of Marketing Science, Vol. 29 No. 2, pp. 115-134.

Marcovitz, Y., Davis, A.J. and Van Dick, R. (2007), "Organizational commitment profiles and job satisfaction among Greek private and public sector employees", International Journal of Cross Cultural Management, Vol. 7, pp. 77-99.

Megheirkouni, M. (2016), "Leadership development methods and activities: content, purposes, and implementation”, Journal of Management Development, Emerald Group Publishing Limited, Vol. 35 No. 2, pp. 237-260.

Mesu, J., Van Riemsdijk, M. and Sanders, K. (2012), "Labour flexibility in SMEs: the impact of leadership”, Employee Relations, Emerald, Vol. 35 No. 2, pp. 120-138.

Meyer, J.P. and Allen, N.J. (1991), "A three-component conceptualization of organizational commitment”, Human Resource Management Review, Elsevier, Vol. 1 No. 1, pp. 61-89.

Meyer, J.P. and Herscovitch, L. (2001), "Commitment in the workplace: toward a general model", Human Resource Management Review, Elsevier, Vol. 11 No. 3, pp. 299-326.

Meyer, J.P., Stanley, D.J., Herscovitch, L. and Topolnytsky, L. (2002), "Affective, continuance, and normative commitment to the organization: a meta-analysis of antecedents, correlates, and consequences", Journal of Vocational Behavior, Vol. 61 No. 1, pp. 20-52.

Mitchell, G.E. (2015), "The attributes of effective NGOs and the leadership values associated with a reputation for organizational effectiveness", Nonprofit Management and Leadership, Wiley Online Library, Vol. 26 No. 1, pp. 39-57.

Nahum-Shani, I. and Somech, A. (2011), "Leadership, OCB and individual differences: idiocentrism and allocentrism as moderators of the relationship between transformational and transactional leadership and OCB", The Leadership Quarterly, JAI, Vol. 22 No. 2, pp. 353-366.

Nguni, S., Sleegers, P. and Denessen, E. (2006), “Transformational and transactional leadership effects on teachers' job satisfaction, organizational commitment, and organizational citizenship behavior in primary schools: the Tanzanian case", School Effectiveness and School Improvement, Routledge, Vol. 17 No. 2, pp. 145-177.

Nielsen, T.M., Bachrach, D.G., Sundstrom, E. and Halfhill, T.R. (2012), "Utility of OCB: organizational citizenship behavior and group performance in a resource allocation framework", Journal of Management, SAGE Publications, Vol. 38 No. 2, pp. 668-694.

Organ, D.W. (1997), “Organizational citizenship behavior: it's construct clean-up time”, Human Performance, Routledge, Vol. 10 No. 2, pp. 85-97.
Leadership styles in nonprofit organizations 
$\mathrm{JMD}$ $39,7 / 8$

Padmanathan, S.R. (2010), Leadership Styles and Employee Engagement, Universiti Utara Malaysia, Kedah.

Parker, S.K. and Griffin, M.A. (2011), "Understanding active psychological states: embedding engagement in a wider nomological net and closer attention to performance", European Journal of Work and Organizational Psychology, Routledge, Vol. 20 No. 1, pp. 60-67.

Park, S., Kim, J., Park, J. and Lim, D.H. (2018), "Work engagement in nonprofit organizations: a conceptual model”, Human Resource Development Review, SAGE Publications, Vol. 17 No. 1, pp. 5-33.

Parsehyan, B.G. (2017), Leadership in Non-Profit Organisations, Contemporary Leadership Challenges, Aida Alvinius, IntechOpen, doi 10.5772/65268, available at: https://www.intechopen.com/books/ contemporary-leadership-challenges/leadership-in-non-profit-organisations.

Parry, K.W. and Sinha, P.N. (2005), "Researching the trainability of transformational organizational leadership", Human Resource Development International, Taylor \& Francis, Vol. 8 No. 2, pp. 165-183.

Piccolo, R.F. and Colquitt, J.A. (2006), "Transformational leadership and job behaviors: the mediating role of core job characteristics", Academy of Management Journal, Vol. 49 No. 2, pp. 327-340.

Podsakoff, P.M. and Organ, D.W. (1986), "Self-reports in organizational research: problems and prospects", Journal of Management, SAGE Publications, Vol. 12 No. 4, pp. 531-544.

Podsakoff, P.M., MacKenzie, S.B., Moorman, R.H. and Fetter, R. (1990), "Transformational leader behaviors and their effects on followers' trust in leader, satisfaction, and organizational citizenship behaviors”, The Leadership Quarterly, JAI, Vol. 1 No. 2, pp. 107-142.

Podsakoff, P.M., MacKenzie, S.B., Paine, J.B. and Bachrach, D.G. (2000), "Organizational citizenship behaviors: a critical review of the theoretical and empirical literature and suggestions for future research", Journal of Management, SAGE Publications, Vol. 26 No. 3, pp. 513-563.

Podsakoff, P.M., MacKenzie, S.B., Lee, J.Y. and Podsakoff, N.P. (2003), "Common method biases in behavioral research: a critical review of the literature and recommended remedies", Journal of Applied Psychology, Vol. 88 No. 5, pp. 879-903.

Podsakoff, N.P., Podsakoff, P.M., MacKenzie, S.B., Maynes, T.D. and Spoelma, T.M. (2014), "Consequences of unit-level organizational citizenship behaviors: a review and recommendations for future research", Journal of Organizational Behavior, John Wiley \& Sons, Vol. 35 No. S1, pp. S87-S119.

Preacher, K.J. and Hayes, A.F. (2004), "SPSS and SAS procedures for estimating indirect effects in simple mediation models", Behavior Research Methods, Instruments \& Computers, Vol. 36 No. 4, pp. 717-731, doi: 10.3758/BF03206553.

Purvanova, R.K., Bono, J.E. and Dzieweczynski, J. (2006), "Transformational leadership, job characteristics, and organizational citizenship performance", Human Performance, Routledge, Vol. 19 No. 1, pp. 1-22.

Quintana, T.A., Park, S. and Cabrera, Y.A. (2015), "Assessing the effects of leadership styles on employees' outcomes in international luxury hotels", Journal of Business Ethics, Vol. 129 No. 2, pp. 469-489.

Rafferty, A.E. and Griffin, M.A. (2004), "Dimensions of transformational leadership: conceptual and empirical extensions", The Leadership Quarterly, JAI, Vol. 15 No. 3, pp. 329-354.

Ramezaninezhad, R., Hematinezhad, M.A. and Andam, R.Z. (2011), "Saba and Sadegh poor, Nemat ollah.(2009)" the relationship between transformational and transactional leadership styles of school administrators and physical education teachers' organizational commitment", Education in Science, Second Year, No. 9.

Rana, S., Ardichvili, A. and Tkachenko, O. (2014), "A theoretical model of the antecedents and outcomes of employee engagement: dubin's method", Journal of Workplace Learning, Emerald, Vol. 26 Nos. 3/4, pp. 249-266. 
Reed, J. and Ferrari, J.R. (2017), "Permanent deacons and non-profit directors: comparing leadership styles among facilitators of community agencies", Review of Religious Research, Springer, Vol. 59 No. 1, pp. 21-29.

Riggio, R.E. (2009), “Charisma”, in Lopez, S.J. (Ed.), Encyclopedia of Positive Psychology, Blackwell, Oxford.

Robertson, I.T. and Cooper, C.L. (2010), "Full engagement: the integration of employee engagement and psychological wellbeing", Leadership and Organization Development Journal, Emerald, Vol. 31 No. 4, pp. 324-336.

Rowold, J. and Rohmann, A. (2009), "Transformational and transactional leadership styles, followers' positive and negative emotions, and performance in German nonprofit orchestras", Nonprofit Management and Leadership, Wiley Online Library, Vol. 20 No. 1, pp. 41-59.

Rowold, J., Borgmann, L. and Bormann, K. (2014), "Which leadership constructs are important for predicting job satisfaction, affective commitment, and perceived job performance in profit versus nonprofit organizations?", Nonprofit Management and Leadership, Wiley Online Library, Vol. 25 No. 2, pp. 147-164.

Sabella, A.R., El-Far, M.T. and Eid, N.L. (2016), "The effects of organizational and job characteristics on employees' organizational commitment in arts-and-culture organizations", International Journal of Organizational Analysis, Emerald Group Publishing, Vol. 24 No. 5, pp. 1002-1024.

Sarti, D. (2014), "Leadership styles to engage employees: evidence from human service organizations in Italy", Journal of Workplace Learning, Emerald, Vol. 26 Nos. 3/4, pp. 202-216.

Sayadi, Y. (2016), "The effect of dimensions of transformational, transactional, and non-leadership on the job satisfaction and organizational commitment of teachers in Iran", Management in Education, SAGE Publications, Vol. 30 No. 2, pp. 57-65.

Schaufeli, W.B., Salanova, M., González-Romá, V. and Bakker, A.B. (2002), "The measurement of engagement and burnout: a two sample confirmatory factor analytic approach", Journal of Happiness Studies, Springer, Vol. 3 No. 1, pp. 71-92.

Schaufeli, W.B., Bakker, A.B. and Salanova, M. (2006), "The measurement of work engagement with a short questionnaire: a cross-national study”, Educational and Psychological Measurement, Sage Publications Sage CA, Thousand Oaks, CA, Vol. 66 No. 4, pp. 701-716.

Seibert, S.E., Wang, G. and Courtright, S.H. (2011), "Antecedents and consequences of psychological and team empowerment in organizations: a meta-analytic review", Journal of Applied Psychology, American Psychological Association, Seibert, Scott E.: Department of Management and Organizations, Tippie College of Business, University of Iowa, 108 John Pappajohn Business Building, Iowa City, IA, US, 52242-1994, scott-seibert@uiowa.edu.

Shiva, M.M. and Suar, D. (2012), "Transformational leadership, organizational culture, organizational effectiveness, and programme outcomes in non-governmental organizations", Voluntas: International Journal of Voluntary and Nonprofit Organizations, Vol. 23 No. 3, pp. 684-710.

Sirianni, P.M. and Frey, B.A. (2001), "Changing a culture: evaluation of a leadership development program at mellon financial services", International Journal of Training and Development, Wiley Online Library, Vol. 5 No. 4, pp. 290-301.

Slocum, J.W. and Hellriegel, D. (2007), "Fundamentals of organizational behaviour", Thomson/SouthWestern, available at: https://books.google.com.om/books?id=GG3XAQAACAAJ.

Spitzbart, I. (2013), "The impact of transactional versus transformational leadership on job satisfaction in the hotel industry", Research in Hospitality Management, Routledge, Vol. 3 No. 1, pp. 69-76.

Tims, M., Bakker, A.B. and Xanthopoulou, D. (2011), "Do transformational leaders enhance their followers' daily work engagement?”, The Leadership Quarterly, Elsevier, Vol. 22 No. 1, pp. 121-131.
Leadership styles in nonprofit organizations 
$\mathrm{JMD}$ $39,7 / 8$

Turner, J.R. and Müller, R. (2005), "The project manager's leadership style as a success factor on projects: a literature review", Project Management Journal, SAGE Publications Sage CA, Los Angeles, CA, Vol. 36 No. 2, pp. 49-61.

Vecchio, R.P., Justin, J.E. and Pearce, C.L. (2008), "The utility of transactional and transformational leadership for predicting performance and satisfaction within a path-goal theory framework", Journal of Occupational and Organizational Psychology, Wiley Online Library, Vol. 81 No. 1, pp. $71-82$.

Vecina, M.L., Chacón, F., Marzana, D. and Marta, E. (2013), "Volunteer engagement and organizational commitment in nonprofit organizations: what makes volunteers remain within organizations and feel happy?”, Journal of Community Psychology, Vol. 41 No. 3, pp. 291-302.

Walumbwa, F.O. and Lawler, J.J. (2003), "Building effective organizations: transformational leadership, collectivist orientation, work-related attitudes and withdrawal behaviours in three emerging economies", The International Journal of Human Resource Management, Routledge, Vol. 14 No. 7, pp. 1083-1101.

Walumbwa, F.O., Orwa, B., Wang, P. and Lawler, J.J. (2005), "Transformational leadership, organizational commitment, and job satisfaction: a comparative study of Kenyan and US financial firms", Human Resource Development Quarterly, Wiley Online Library, Vol. 16 No. 2, pp. 235-256.

Wang, G., Oh, I.-S., Courtright, S.H. and Colbert, A.E. (2011), "Transformational leadership and performance across criteria and levels: a meta-analytic review of 25 Years of research", Group and Organization Management, SAGE Publications, Vol. 36 No. 2, pp. 223-270.

Whittington, J.L., Coker, R.H., Goodwin, V.L., Ickes, W. and Murray, B. (2009), "Transactional leadership revisited: self-other agreement and its consequences", Journal of Applied Social Psychology, John Wiley \& Sons, (10.1111), Vol. 39 No. 8, pp. 1860-1886.

Williams, L.J. and Anderson, S.E. (1991), "Job satisfaction and organizational commitment as predictors of organizational citizenship and in-role behaviors", Journal of Management, SAGE Publications, Vol. 17 No. 3, pp. 601-617.

Wollard, K.K. and Shuck, B. (2011), "Antecedents to employee engagement: a structured review of the literature", Advances in Developing Human Resources, SAGE Publications, Vol. 13 No. 4, pp. 429-446.

Woods, R.H. and King, J.Z. (2012), Leadership and Management in the Hospitality Industry, 3rd ed., Educational Institute of the American Hotel Motel Assoc, Orlando, Florida.

Yao, Y.-H., Fan, Y.-Y., Guo, Y.-X. and Li, Y. (2014), "Leadership, work stress and employee behavior”, Chinese Management Studies, Emerald Group Publishing, Vol. 8 No. 1, pp. 109-126.

Yukl, G.A. (2010), Leadership in Organizations, 7th ed., Pearson Prentice Hall, New Jersey.

Yıldız, I.G. and Simşek, Ö.F. (2016), "Different pathways from transformational leadership to job satisfaction: the competing mediator roles of trust and self-efficacy", Nonprofit Management and Leadership, Wiley Online Library, Vol. 27 No. 1, pp. 59-77.

Yıldız, S., Baştürk, F. and Boz, İ.T. (2014), "The effect of leadership and innovativeness on business performance", Procedia-Social and Behavioral Sciences, Elsevier, Vol. 150, pp. 785-793.

Zigarmi, D., Blanchard, K., O'Connor, M. and Edeburn, C. (2004), The Leader within: Learning Enough about Yourself to Lead Others, FT Press.

\section{Further reading}

Albrecht, S. (2005), "Leadership climate in the public sector: feelings matter too!", Intl Journal of Public Administration, Taylor \& Francis, Vol. 28 Nos. 5/6, pp. 397-416.

Bass, B.M. (1998), "Transformational leadership: industrial, military, and educational impact", Lawrence Erlbaum Associates, available at: https://books.google.com.om/books?id=7zqsNAEACAAJ. 
Blomme, R.J., Kodden, B. and Beasley-Suffolk, A. (2015), "Leadership theories and the concept of work engagement: creating a conceptual framework for management implications and research", Journal of Management and Organization, Cambridge University Press, Vol. 21 No. 2, pp. 125-144.

De Cremer, D. (2003), "Why inconsistent leadership is regarded as procedurally unfair: the importance of social self-esteem concerns", European Journal of Social Psychology, John Wiley \& Sons, Vol. 33 No. 4, pp. 535-550.

Han, S.H., Seo, G., Yoon, S.W. and Yoon, D. (2016), "Transformational leadership and knowledge sharing: mediating roles of employee's empowerment, commitment, and citizenship behaviors", Journal of Workplace Learning, Vol. 28 No. 3, pp. 130-149.

Kotter, J. (1996), Leading Change, Harvard Business School Press, Cambridge, MA.

LePine, M.A., Zhang, Y., Crawford, E.R. and Rich, B.L. (2015), "Turning their pain to gain: charismatic leader influence on follower stress appraisal and job performance", Academy of Management Journal, Vol. 59 No. 3, pp. 1036-1059.

Neckermann, S., Cueni, R. and Frey, B.S. (2014), "Awards at work”, Labour Economics, Vol. 31, pp. 205-217.

Schmitt, A., Den Hartog, D.N. and Belschak, F.D. (2016), "Transformational leadership and proactive work behaviour: a moderated mediation model including work engagement and job strain", Journal of Occupational and Organizational Psychology, John Wiley \& Sons, (10.1111), Vol. 89 No. 3, pp. 588-610.

\section{Corresponding author}

Mohammed Aboramadan can be contacted at: mohammed.aboramadan@unimib.it

\section{Leadership styles in nonprofit organizations}

